\title{
RELEVANSI NILAI INFORMASI NON KEUANGAN
}

\author{
Resa Cantika ${ }^{1}$, Ryan Suryadi ${ }^{2}$, Ida Farida Adi Prawira ${ }^{3}$, Arim Nasim ${ }^{4}$ \\ ${ }^{1234}$ Program Studi Akuntansi, Fakultas Pendidikan Ekonomi dan Bisnis, \\ Universitas Pendidikan Indonesia, Bandung, Indonesia \\ resacantika@student.upi.edu ${ }^{1}$,ryansuryadi15@student.upi.edu ${ }^{2}$, ida.farida@upi.edu ${ }^{3}$,arim.nasim@upi.edu ${ }^{4}$
}

\begin{abstract}
The relevance of the value of financial statement information can be increased by combine non-financial information. This article examines several previous research articles conducted in various countries that have different characteristics regarding the influence of non-financial information on value relevance with the intention to find out more the influence of non-financial information on the value of company relevance. The research method used in this article is descriptive analytic with reference sources derived from scientific journals related to the relevance of values in non-financial information. The scientific articles that used as a references is five articles. The conclusion from this study is that not all non-financial information has value relevance. The type of non-financial information that can be transferred directly by the company is considered to have relevance to the company's value, and vice versa. The article is expected can used for other researcher to examine more about the influence and correlation of non-financial information on value relevance or other things.
\end{abstract}

Keywords: company's value; non-financial information; value relevance

\begin{abstract}
Abstrak
Relevansi nilai informasi laporan keuangan dapat ditingkatkan jika dikombinasikan dengan informasi non keuangan. Artikel ini mengkaji beberapa artikel penlitian sebelumya yang dilakukan di berbagai negara yang memiliki karakteristik yang berbeda mengenai pengaruh informasi non keuangan terhadap relevansi nilai dengan tujuan untuk mengetahui seberapa besar pengaruh informasi non keuangan terhadap nilai relevansi perusahaan. Metode penelitian yang digunakan dalam artikel ini yaitu deskriptif analitik dengan sumber referensi yang berasal dari jurnal ilmiah yang berhubungan dengan relevansi nilai pada informasi non keuangan. Artikel ilmiah yang digunakan sebagai referensi utama adalah lima artikel. Hasil kesimpulan dari studi ini adalah bahwa tidak semua informasi non keuangan memiliki relevansi nilai. Jenis informasi non keuangan yang dapat dikendalikan langsung oleh perusahaan dianggap memiliki relevansi dengan nilai perusahaan, begitupun sebaliknya. Artikel ini diharapkan mampu memicu bagi peneliti lain untuk meniliti lebih jauh mengenai peranan serta hubungan informasi non-keuangan terhadap relevansi nilai atau hal lainnya.
\end{abstract}

Kata Kunci: informasi non-keuangan; nilai perusahaan; relevansi nilai Corresponding author: Email : resacantika@ student.upi.edu

History of article : Received: Juli 2019, Revised : September 2019, Published: November 2019 


\section{PENDAHULUAN}

Secara umum, pengungkapan kondisi keuangan menjadi faktor utama sebagai informasi yang dibutuhkan oleh pemangku kepentingan. Dimana keadaan keuangan suatu perusahaan dapat menggambarkan kondisi perusahaan tersebut (Caserio \& Napoli, 2017; Hughes, 2000). Hal yang paling penting yang membuat informasi akuntansi berguna bagi investor adalah konsep relevansi nilai. Karena dengan relevansi nilai dapat memberikan informasi yang relevan kepada investor mengenai perusahaan berdasarkan harga saham (Caserio and Napoli 2017).

Namun, beberapa peneliti terdahulu menyatakan bahwa laporan keuangan telah kehilangan porsi yang signifikan relevansinya dengan investor(Hughes 2000). Agar laporan keuangan memiliki relevansi nilai, laporan keuangan tersebut harus akurat dan transparan. Sehingga dapat memberikan informasi yang dibutuhkan oleh pemangku kepantingan(Variables 2015).

Laporan keuangan tidaklah cukup untuk menjadi dasar informasi bagi investor. Diperlukannya informasi tambahan untuk memenuhi kebutuhan tersebut (Flöstrand and Ström 2006). Relevansi nilai informasi laporan keuangan dapat ditingkatkan jika dikombinasikan dengan informasi akuntansi non keuangan. Selama dua dekade terakhir, minat dalam pengungkapan informasi non keuangan pada perusahaan telah bertumbuh pesat. Para pemangku kepentingan telah mempertimbangkan bahwa informasi non keuangan merupakan hal yang krusial. Maka dari itu, banyak perusahaan yang mulai mengungkapkan informasi non keuangan

Informasi non keuangan terdiri dari data kuantitatif dan kualitatif tentang kebijakan yang diambil, bisnis operasi dan yang lainnya dengan hasil yang tanpa ada hubungan dengan informasi keuangan(Variables 2015). Tidak seperti informasi laporan keuangan, pelaporan informasi non keuangan masih relatif baru dan belum ada prinsif secara umum diterima.

Penelitian-penelitian di berbagai Negara sebelumnya mengatakan bahwa nilai informasi non keuangan memiliki peran penting dalam pengambilan keputusan variabel non keuangan sebagai penunjang. Oleh karena itu, artikel ini mengkaji pengaruh informasi non keuangan terhadap relevansi nilai di berbagai Negara yang memiliki karakteristik yang berbeda.

\section{KAJIAN PUSTAKA Value Relevance}

$\begin{array}{rrr}\text { Value } & \text { Relevance } & \text { (relevansi nilai) } \\ \text { didefinisikan } & \text { sebagai } & \text { kemampuan }\end{array}$ pengukuran akuntansi atau non-akuntansi untuk menangkap atau meringkas informasi yang mempengaruhi nilai ekuitas. Model ini mengungkapkan nilai pasar ekuitas sebagai fungsi dari nilai buku perusahaan, pendapatan, dan informasi non-keuangan yang relevan dengan nilai lainnya (Hassel, Nilsson, and Nyquist 2005).

$\begin{array}{cccc}\text { Ernest } & \& & \text { Oscar } & \text { (2014) } \\ \text { mendefinisikan } & \text { konsep } & \text { relevansi } & \text { nilai }\end{array}$ informasi akuntansi sebagai kegunaan informasi akuntansi keuangan, mengingat keputusan investor untuk berinvestasi atau mempertahankan investasi mereka dalam saham perusahaan yang timbul dari hubungan antara laporan keuangan dan harga saham. Mayoritas literatur relevansi nilai juga berkaitan dengan bagaimana pengukuran akuntansi mempengaruhi perubahan nilai pasar ekuitas, yaitu, return saham (Beisland 2009). Penelitian relevansi nilai secara dominan signifikan bagi investor, praktisi akuntansi, regulator dan pihak berkepentingan lain yang menggunakan informasi akuntansi untuk keputusan investasi (Badu and Appiah 2018). 


\section{Non-Financial Information}

Informasi non-keuangan adalah didefinisikan sebagai informasi tentang kinerja entitas yang tidak dinyatakan dalam unit moneter (Haller et al. 2017). Informasi non-keuangan sangat penting untuk memahami kinerja apa yang ada pada sebagian besar entitas nirlaba, yang beroperasi untuk keuntungan pribadi. Informasi non-keuangan juga sama pentingnya dengan informasi keuangan dalam proses pengambilan keputusan serta dapat menjadi hasil yang menarik jika digunakan dengan benar(Mbabazize et al. 2015).

Selain itu, Orens \& Lybaert mengungkapkan bahwa analis keuangan juga menggunakan informasi non-keuangan dalam memperkirakan kinerja perusahaan di masa depan dan nilai perusahaan. Perusahaan yang mengeluarkan informasi non-keuangan dalam jumlah yang lebih besar memungkinkan analis keuangan untuk melaporkan perkiraan pendapatan yang lebih akurat dan untuk memberikan perkiraan pendapatan yang lebih sedikit. Bukti berdasarkan survei dan analisis isi laporan analis juga menunjukkan meningkatnya penggunaan informasi nonkeuangan oleh analis keuangan dari waktu ke waktu.

Informasi non-keuangan meliputi semua data kuantitatif dan kualitatif pada kebijakan yang diikuti, operasi bisnis dan hasil kebijakan dalam bentuk hasil, tanpa hubungan langsung dengan sistem registrasi keuangan. Informasi non-keuangan mengacu pada informasi yang berada di luar ruang lingkup laporan keuangan arus utama dan tidak memiliki dampak keuangan langsung. Terkadang informasi non-keuangan dapat merujuk pada akuntansi sosial, tanggung jawab sosial perusahaan, pelaporan lingkungan, keberlanjutan, pelaporan kinerja layanan dan sebagainya (Malek-yonan, Bakhtiar, and Rafsanjani 2016).

\section{METODE PENELITIAN}

Metode penelitian yang digunakan dalam makalah ini adalah deskriptif analitik. Langkah yang paling pertama dilakukan dalam penulisan adalah proses pencarian data. Adapun data yang digunakan dalam artikel ini adalah data sekunder. Data sekunder adalah data yang mengacu pada informasi yang dikumpulkan dari sumber yang telah ada (Uma Sekaran : 2011). Dimana data ini didapatkan dari hasil penelitian terdahulu yang relevan dengan topic artikel yang dibahas, yaitu mengenai value relevance dan non financial informationyang bersumber dari Google Scholar, Taylor and Francis, DOAJ (Directory of Open AccessJournal), IJARCSMS, EconJournals, Elsevier, SAGE Journals, JSTOR, Research Gate, Springer Open dan Emerald Insight. Dengan memasukan kata kunci "Value Relevance" pada sumber di atas memunculkan artikel rata-rata sebanyak 830.000 artikel. Selanjutnya dilakukanpengunduhan artikel yang berhubungan dengan topik yang akan dibahas sebanyak 81 artikel. Kemudian dilakukan penyaringan kembali yang lebih spesifik berdasarkan variabel relevansi nilai yang memuatinformasi non keuangan sehingga didapatkan 36 artikel yang akan digunakan dengan artikel utama yang dipilih sebanyak 8 artikel.

Teknik penyaringan yang dilakukan adalah :

a. Membaca abstrak dari atikel yang berhubungan dengan value relevance sampai menemukan artikel yang relevan, kemudian unduh.

b. Membaca dan menganalisis semua artikel yang telah diunduh. Kemudian memisahkan antara artikel yang menggunakan variabel keuangan dengan variabel keuangan.

c. Memilih variabel non keuangan dengan karakter negara yang berbeda sebagai referensi artikel utama. 


\section{HASIL DAN PEMBAHASAN}

Pengungkapan informasi non keuangan bertumbuh pesat di perusahaan dan menjadi penunjang dalam menilai relevansi nilai informasi laporan keuangan. Dalam penentuan keputusan, investor tidak cukup menilai hanya dari segi laporan keuangan saja, namun memerlukan hal yang lebih transparan dan berintegritas sehingga membutuhkan tambahan informasi dari faktor-faktor non-keuangan. Perbedaan yang terjadi antara nilai pasar dengan nilai buku perusahaan karena ada inovasi dan pemasaran perusahaan, dari hal tersebut ditemukan bahwa ada pergeseran dari asset berwujud ke tidak berwujud(Amir and Lev (1996); Ittner and Larcker (1998)).

Adanya penurunan signifikan dari relevansi dan kegunaan laporan keuangan karena tidak diungkapkannya asset tak berwujud dalam neraca alasannya karena transformasi ekonomi, pertumbuhan dari asset tak berwujud serta kecerdasan manusia yang menyebabkan laporan keuangan saja tidak cukup untuk menilai perusahaan(Hyon and Kang 2006). Asset tak berwujud pengetahuan manajemen menjadi kunci keberhasilan dalam industri karena asset berwujud saja tidak cukup untuk mengevaluasi nilai perusahaan sehingga menimbulkan perbedaan dalam nilai pasar dengan nilai buku perusahaan (Liang and Yao (2005); Modi (2016)).

Variabel informasi non keuangan yang mempengaruhi relevansi nilai yang ditemukan pada perusahaan di beberapa Negara diantaranya variabel kinerja lingkungan, emisi lingkungan, pengendalian internal yang kurang efektif,merek dan kode etik.

\section{Hubungan Kinerja Lingkungan dengan Relevansi Nilai}

Pemegang saham tertentu menunjukkan perhatian yang lebih besar mengenai masalah lingkungan. Semakin pentingnya investasi yang bertanggung jawab secara sosial menunjukkan bahwa investor lebih tertarik pada praktik sosial dan lingkungan perusahaan. Hal ini menunjukkan bahwa investor menjadi lebih tertarik pada apakah kinerja lingkungan perusahaan dapat meningkatkan kekayaan mereka (Nelwan 2016).Pasar keuangan memiliki banyak informasi lingkungan dari berbagai sumber dari internal atau eksternal perusahaan yang mengukur berbagai dimensi kinerja lingkungan, yang meningkatkan kompleksitas pengambilan keputusan (Ilinitch, Soderstrom, dan Thomas (1998); Moneva \& Cuellar (2009)).

Pelaporan lingkungan dapat meningkatkan pengambilan keputusan investor karena kinerja lingkungan suatu perusahaan mungkin memiliki dampak langsung pada posisi keuangannya(Richardson and Welker 2001). Berdasarkan penelitian Moneva dan Cuellar (2009) pada laporan tahunan perusahaan yang terdaftar pada Madrid Stock Exchange menunjukkan bahwa pengungkapan lingkungan non keuangan tidak relevan dengan kinerja lingkungan. Pada penelitian tersebut, Moneva dan Cuellar menggunakan indicator keuangan dan non keuangan, yaitu cost, provision, contingencies, policy dan EMS. Hal tersebut juga diperjelas dengan hasil yang menunjukkan bahwa kombinasi pelaporan keuangan dengan pengukuran lingkungan non-keuangan tidak meningkatkan kekuatan penjelas harga saham.

\section{Hubungan Emisi Lingkungan Dengan Relevansi Nilai}

Seperti yang dipaparkan sebelumnya bahwa investor memiliki ketertarikan mengenai kinerja lingkungan perusahaan. Kinerja lingkungan dalam bentuk emisi dapat menjadi indikator paparan perusahaan terhadap biaya atau kewajiban lingkungan di masa depan. Emisi yang lebih rendah dapat 
mengindikasikan manajemen yang baik pada proses produksi dan limbah. Meskipun mengelola proses produksi untuk mengurangi emisi menambah biaya dan mengurangi pendapatan saat ini, tetapi perusahaan mungkin lebih baik dengan memiliki produksi dan output yang lebih bersih di masa depan, menarik lebih banyak pelanggan yang peduli lingkungan, serta mendapatkan reputasi lingkungan yang baik. Semua hal ini dapat dihormati sebagai pengamanan legitimasi perusahaan, meningkatkan keunggulan kompetitif dan meningkatkan nilai perusahaan.Bagi para investor, penciptaan nilai ini meningkatkan arus kas masa depan yang diharapkan dan membuat mereka menyesuaikan harga saham secara positif(Nelwan 2016).

Dalam penelitian yang dilakukan oleh Nelwan (2016) pada perusahaanperusahaan Amerika Serikat menemukan bahwa ada keterkaitan antara pengungkapan emisi yang dilakukan oleh perusahaan dengan nilai perusahaan. Dalam penelitian tersebut juga ditemukan bahwa hanya emisi tanah yang berkaitan dengan harga saham, sehingga dalam hal ini tidak dapat digeneralisasikan seluruh emisi dapat berkaitan terhadap harga saham. Dalam hal ini, penilaian emisi tidak dapat diagregasikan karena hanya dapat menyesatkan sehingga perusahaan perlu untuk memilah penilaian emisinya. Namun, beberapa faktor perlu perhatian khusus karena ketatnya regulasi serta peliputan media yang ada. Sehingga dalam pengungkapan beberapa data emisi perusahaan harus mempertimbangkan efek moderat dari biaya kepatuhan.

\section{Hubungan Pengendalian Internal Yang Kurang Efektif Dengan Relevansi Nilai}

Pengendalian internal yang efektif atas pelaporan keuangan secara luas diakui sebagai hal mendasar bagi sistem informasi berkualitas tinggi dan informasi keuangan berkualitas tinggi(Ashbaugh-Skaife et al. 2009). Faktor pengendalian internal yang kurang efektif dapat berpengaruh terhadap penilaian perusahaan. Pengendalian internal yang kurang efektif menghasilkan pelaporan keuangan yang kurang andal, sehingga meningkatkan informasi risiko yang dihadapi oleh investor yang bermanifestasi dalam biaya ekuitas yang lebih tinggi (Ashbaugh-Skaife et al. 2009).Pengendalian internal yang kurang efektif secara signifikan dan negatif terkait dengan nilai pasar perusahaan serta dapat mengurangi relevansi nilai pendapatan dan nilai buku ekuitas dalam menentukan nilai pasar perusahaan. Hal tersebut juga dapat mempengaruhi penilaian dan menarik wawasan tentang bagaimana investor membuat keputusan penilaian mereka berdasarkan pada adanya defisiensi pengendalian internal (Hu et al. 2013).

The Sarbanes-Oxley Act (SOX) merupakan aturan yang memaksa perusahaan yang listing di bursa saham Amerika untuk memperbaiki pengungkapan laporan keuangannya demi keintegritasan sebuah laporan keuangan. Kepatuhan terhadap ketentuan SOX didasari pada bahwa pengendalian internal yang efektif memberikan manfaat yang signifikan bagi investor dengan mengurangi salah saji yang disengaja dan tidak disengaja dalam mengukur, mencatat, dan memproses informasi keuangan, sehingga menghasilkan laporan keuangan yang lebih andal( $\mathrm{Hu}$ et al. 2013).

\section{Hubungan Merek Dagang (Brand) Dengan Relevansi Nilai}

Merek dagang (brand) dapat dikategorikan dalam asset tak berwujud yang dapat dijadikan tambahan informasi bagi nilai saham. Kegunaan informasi tersebut dapat digunakan bagi investor maupun stakeholders. Perhitungan merek dagang menggunakan perhitungan royalty 
yang didapatkan yang mempengaruhi perhitungan laba dari perusahaan. Hal tersebut tentunya dapat membantu perhitungan nilai perusahaan (Bagna et al. 2017).

\section{Hubungan Kode Etik Dengan Relevansi Nilai}

Kode etik merupakan salah satu informasi tambahan yang dapat dipertimbangkan untuk mengukur nilai suatu perusahaan serta dapat digunakan investor untuk mempertimbangkan keputusannya. Selain itu, kode etik dapat dijadikan bahan oleh investor untuk mengevaluasi nilai perusahaan. Pada artikel ini, penulis menggunakan sampel perusahan yang memiliki kode etik yang berkualitas tinggi dan perusahaan yang baru menerapkan kode etik. Dari sampel tersebut menunjukan hasil bahwa kode etik yang berkualitas tinggi serta kode etik yang baru diterapkan memiliki relevansi nilai. Meskipun demikian, penulis mengatakan bahwa secara umum kode etik dalam kondisi apapun memiliki relevansi nilai.

Hal ini membantu perusahaan untuk mulai menerapkan kode etik sebagai tambahan informasi akuntansi bagi penilaian perusahaan ataupun bagi yang sudah menerapkan kode etik untuk dapat memperbaiki menjadi jadi lebih baik lagi(Caserio and Napoli 2017).

\section{KESIMPULAN DAN SARAN}

Dalam penentuan keputusan ekonomi, investor tidak hanya mempertimbangkan laporan keuangan saja tetapi juga memerlukan informasi tambahan seperti informasi non keuangan. Dimana beberapa informasi non keuangan memiliki nilai relevansi dengan laporan keuangan perusahaan.Berdasarkan analisis yang dilakukan oleh penulis, variabel pengendalian internal yang kurang efektif, merek dan kode etik perusahaan memiliki relevansi dengan nilai perusahaan yang dapat mempengaruhi perhitungan laba. Sedangkan, variabel kinerja lingkungan dan emisi lingkungan tidak memiliki relevansi dengan nilai perusahaan tetapi masih menjadi hal yang dipertimbangkan oleh investor dalam proses pengambilan keputusan.

Maka dapat disimpulkan bahwa tidak semua informasi non keuangan memiliki nilai relevansi. Jenis informasi non keuangan yang dapat dikendalikan langsung oleh perusahaan dianggap memiliki relevansi dengan nilai perusahaan. Sebaliknya, jenis informasi non keuangan yang tidak dapat dikendalikan langsung oleh perusahaan dianggap tidak memiliki keterkaitan dengan nilai perusahaan. Keterbatasan dalam artikel ini yaitu jumlah variabel yang digunakan terlalu sedikit sehingga hasil yang disimpulkan tidak dapat digeneralisasikan karena tidak cukup untuk mewakili semua jenis informasi non keuangan. Selain itu juga kurangnya literature mengenai nilai relevansi pada informasi non keuangan sebagai referensi utama. Maka, diperlukannya penelitian lanjutan untuk menyempurnakan artikel ini. Penelitian selanjutnya diharapkan dapat menyajikan lebih banyak variabel informasi non keuangan serta referensi yang akurat sebagai sumber utama.

\section{DAFTAR PUSTAKA}

Amir, Eli, and Baruch Lev. (1996). ValueRelevance of Nonfinancial Information: The Wirless Communications Industry. Journal of Accounting and Economics 22: 3-30.

Ashbaugh-Skaife, Hollis, Daniel W. Collins, William R. Kinney Jr., and Ryan Lafond. (2009). The Effect of SOX Internal Control Deficiencies on Firm Risk and Cost of Equity.Journal of Accounting Research 47(1). 
Badu, Bismark, and Kingsley Opoku Appiah. (2018). Value Relevance of Accounting Information: An Emerging Country Perspective. Journal of Accounting \& Organizational Change 14(4): 473-91.

Bagna, Emanuel et al. (2017). The Value Relevance of Brand Valuation. Applied Economics 49(58): 5865-76. https://doi.org/10.1080/00036846.2017. 1352078.

Beisland, Leif Atle. (2009). A Review of the Value Relevance Literature. The Open Business Journal 2: 7-27.

Caserio, Carlo, and Francesco Napoli. (2017). Value Relevance and Codes of Ethics: An Empirical Analysis of Italian Listed Companies. International Journal of Business Governance and Ethics 12(1): 1-20.

Ernest, Oshodin, and Mgbame Chijoke Oscar. (2014). The Comparative Study of Value Relevance of Financial Information in The Nigeria Banking and Petroleum Sectors. Journal of Business Studies Quarterly 6(1).

Flöstrand, Per, and Niklas Ström. (2006). The Valuation Relevance of NonFinancial Information. Management Research News 29(9): 580-97.

Haller, Axel et al. (2017). The Term ' NonFinancial Information' - A Semantic Analysis of a Key Feature of Current and Future Corporate Reporting The Term ' Non-Financial Information' A Semantic Analysis of a Key Feature of Current and Future Corporate Reporting. Accounting in Europe.

Hassel, Lars, Henrik Nilsson, and Siv Nyquist. (2005). he Value Relevance of Environmental Performance. European Accounting Review 14(1): 41-61.

$\mathrm{Hu}$, Nan et al. (2013). The Impact of Ineffective Internal Control on the Value Relevance of Accounting Information. Asia-Pasific Journal of
Accounting \& Economics 20(3): 33447.

Hughes, K. E. (2000). The Value Relevance of Nonfinancial Measures of Air Pollution in the Electric Utility Industry. Accounting Review 75(2): 209-28.

Hyon, Helen, and Ju Kang. (2006). Reporting Intangible Asset: Voluntary Disclosure Practices of The Top Emerging Market Companies.

Ilinitch, Anne Y., Naomi S. Soderstrom, and Tom E. Thomas. (1998). Measuring Corporate Environmental Performance. Journal of Accounting and Public Policy 17(4-5): 383-408.

Ittner, Christopher D., and David F. Larcker. (1998). Are Nonfinancial Measures Leading Indicators of Financial Performance? An Analysis of Customer Satisfaction. Journal of Accounting Research 36: 1-35.

Liang, Chiung-Ju, and Ming-Li Yao. (2005). The Value-Relevance of Financial and Nonfinancial Information-Evidence from Taiwan's Information Electronics Industry. Review of Quantitative Finance and Accounting 24: 135-57.

Malek-yonan, Reza, Mahmoud Bakhtiar, and Milad Rafsanjani. (2016). Analytical Study on the Importance of Non-Financial Information in Company Reporting. International Journal of Management and Business Studies 6(3): 251-55.

Mbabazize, Mbabazi, Twesige Daniel, Mazimpaka Claude, and Jaya Shukla. (2015). Reporting of Non-Financial Information and Its Impact on the Decisions Taken in Private Institutions in Rwanda: Case Study in Norhern Province. International Journal of Small Business and Entrepreneurship Research 2(3): 57-71.

Modi, Swati. (2016). A Review on the Literature of Value Relevance of Non 
Financial Variables or Information." International Journal of Advance Research in Computer Science and Management Studies 4(2).

Moneva, José M, and Beatriz Cuellar. (2009). The Value Relevance of Financial and Non-Financial Environmental Reporting. Environ Resource Econ: 441-56.

Nelwan, Melinda Lydia. (2016). The Value Relevance of Environmental Emissions. Journal of Economics, Business, and Accountancy Ventura 19(1): 93-102.

Orens, Raf, and Nadine Lybaert. Disclosure of Non-Financial Information: Relevant to Financial Analysts?" Review of Business and Economic Literature 58(4): 375-405.

Richardson, Alan J., and Michael Welker. (2001). "Social Disclosure, Financial Disclosure and the Cost of Equity Capital." Accounting, Organizations and Society (26): 597-616.

Variables, Accounting. (2015). A Review on the Literature of Value Abstract :3(2): 95- 102. 